\title{
Literary Heritage of G.N. Aygy
}

\author{
Galina A. Ermakova, Olga G. Vladimirova*, Alena M. Ivanova, Anna N. Zakharova, Nadezhda I. Yakimova
}

Chuvash State University named after Ulyanov I.N., Moskovsky Avenue, 15, Cheboksary, Russia

\begin{abstract}
This article focuses on literary heritage and special features of aesthetic concept of Chuvash poet G.N. Aygy. The analysed body of work of this wordsmith represents a natural phase of evolution of national, Russian, foreign literatures which, absorbing several currents, arises as a new phenomenon in the existing artistic system, reflecting both certain characteristics of nonclassical rhetoric and recent trends in public conscience, where search for the meaning is transferred from social and philosophical areas into spheres of intuition and aesthetic. The current interest to the non-classical rhetoric dictates the need to make sense of nuances in Aygy's lyrics, who was able to present through his own literary world the main idea of Chuvash ethnic community - aspiration towards light.
\end{abstract}

\section{Introduction}

Real poetry is the convergent point of «chaos - in space». The haunting forces of chaos were felt by such poets as Dante, Baudelaire, Lermontov, Mayakovsky, Mandelstam, Pasternak, as well as poets, presenting the worldview of Chuvash ethnicity, - Konstantin Ivanov, Michael Sespel. Their tradition was continued in the XX century by Gennady Nikolayevich Aygy. He, as the above mentioned poets, interpreted the examples of spiritual force through the images of Baudelaire, Shalamov, mother, ancestors, god, field, forest, meadow, house, cross, tree, flowers, light.

The power of his artistic and philosophical mind lies in the fact that he tried to enter «the beginning», making sense of it, as so many wanted to do before him, such as Plato, Aristotle, Nikolay Kuzansky, Descartes, Spinoza, Dante and others.

$\mathrm{He}$ is unique, his uniqueness is not granted, but represents an arduous act of creating his own world. Shaping himself as a poet, as a personality, he entered «the universal». Having accepted it, he retained in his worldview the aesthetic principles of his ethnicity.

The poet could combine two mindsets - individual, human, and eternal, infinite, he went from himself into the world and back, this gave him the vitality which helped to create a new space out of «chaotic element».

The work of Gennady Nikolayevich Aygy (Lisin), in spite of its popularity in Russia and European countries, requires interpretation of his aesthetic conception. The master of the pen from Chuvashia managed to reach the forefront of national poetic culture, either Russian, or foreign, develop the ambitious patterns of $\mathrm{V}$. Mayakovsky, V. Khlebnikov, invigorate them, and, thus, present the non-classical rhetoric, adding certain features of realism, modernism, romanticism, symbolism, impressionism. This is aygyism: all-seeing, all-hearing, all-feeling. In the «new poetry», as noted by M.M. Filippov, «the entire mankind must recognize themselves» [1]. The lyric verse of the poet grows from the universe of his people, his own very personal places, like fields, forests, woods he interprets them as universal phenomena. The artistic world of the poet is presented through a peculiar shape, he has no verses where the shape completely coincides that is the power and vigour of his poetry that is based on ever moving spiralling and expanding thought. The opinion of Buffon: «the major merit of style is its relation with thought» [2] was materialized by Aygy. For him it was essential to be able to see, hear, say, express the movement of an idea.

\section{Methodology}

The research materials are lyric verses of G.N. Aygy. The discourse of the poet is interpreted within the current framework of literature studies. This article is written with the help of such methods as analysis, synthesis, comparison and analogy, generalization and abstraction, general-theoretical methods.

\section{Results}

The reality in the fictional world is depicted in light and dark shades, but the impressionist light and lyrical perception of the world is dominant. The poet managed to mix in one stream both the physical object (a rose, phloxes, house, girl, straw), and its subjective perception as well as emotional experience. «The word reflects, and also expresses the variants of world image - multiplicity and singularity of individual experience in man's emotions» [3].

As an example, we take the verse «This year poppies». The vision of blooming poppies, we believe,

\footnotetext{
* Corresponding author: vladolgen@ yandex.ru
} 
was the starting point for this work, though real existing poppies are subjectively perceived as «children» by the poet.

Poppies bloom, in Aygy's point of vew, only when blessed by the touch of «favourable power». Poppy blossoms are compared with the song of a nightingale, with a child, «unaware» of driving force.

The view of poppies blooming generates in the poet's soul strong emotions. The poet compares himself with a flower in bloom, and through this image talks about transience of life, just as poppies wither, so we age.

The origin of this idea, probably, comes from the Chuvash saying: hegh, life is but a poppy petal. The physical object, as A.M.Ivanova claims, generates in the Chuvash ethnic community, similarly to other ethnic groups, the philosophical world view which is presented in proverbs [4].

Describing a real object - poppy, the poet speaks about the meaning of human life, raises the issue of saving a human soul: "we will not save, but the beauty will». The same reasoning can be seen in the articles by L.K. Bairamova, F.F. Gilemshin, V.N. Vassilieva [5]. Through mixing different feelings (pride, sadness, sorrow) he makes us depart from a concrete image and address the philosophical problems: life and death, an instant and eternity. Poppies are like God, they radiate light; «ask» the narrator to find in them «cure».

They have invisible to others power, however, the poet sees this power, feels and expresses it in gracious modulations of pronouns («we» - «you»(singular) «us» - «you»(plural)), the present tense of verbs in the first person plural («grieve» - «save» - «do not hold» «bloom»- «do not know»), the imperative («seek»), the short form of the adjective («beautiful»), the participle («unmoved») serve to describe the emotional state.

Two-dimensionality is transparent: the human life is interpreted through the image of poppies. Forming elements of the work are filled with the philosophical sense. The artistic language fixes the changeability of natural phenomenon - fleetingness of blossom. The scene is realistic, the form of expression is symbolic, the image of poppies is presented in a modernistic way subjectified, emotions are drawn in the impressionistic manner, everything breathes, lives, the changing image of the poppy (blossoming moment) is shown both as light-hearted and philosophical.

We can say that the method of psychological analysis through animation of the matter (idea) and materialization of feelings (delight, sadness, sorrow) is skillfully applied by the poet in the work under study.

The real picture of blooming poppies, «melting» in the mind of the poet, generates the poet's train of thoughts concerning life and death, that «power», which one should see and experience just as the wordsmith has seen and experienced, resulting in the demonstration of the poet's inner world, the core of which is this power that makes the poppies bloom.

The narrator, takes the mundane objects (birch, pine, ravine, poppies, sugar, roman catholic church, temple, houseware), and idealizes them (poppies - «children», poppies - «like a nightingale») with a single purpose - to discover the sense of life. And he finds it: «bloom», «shine», «be» (writing paper is transformed into «fairhaired sister», forest is like a piano, a field seems a miracle, an evening reminds a single rose, a «baby's hug», a day looks like a «river», a poet is universe (a child).

The poet presents his own view of life and world. Through the individual-psychological «I» of the poet, in our opinion, one can perceive the social-epic XX century, his books of poems can serve as historical documents of life of a creative personality in the second half of the XX century.

The elements of realism, symbolism, impressionism, modernism in his work prove that the poet stands against the literature of social realism, continues the traditions of modernistic literature of the XX century, as well as the artistic pattern of searching for insights into the inner world of a man, we believe there is no need to draw an opposition between the innovative Aygy and the traditional Aygy, or between his modernistic side and realistic one, as in his works everything is intertwined, shaping the "new poetry» of the XX century. It seems evident that it is characteristic for Aygy both to subjectify and poetize the world through showing the real moments in life, these reality elements can be seen retrospectively, the poet can imagine and revive the forgotten impressions with the help of an object in a very vivid and bright manner.

For modernistic literary trends it is typical to narrow the sphere of depicted reality, subjectified and mystified presentation of a human and social relations. In modernism a man is shown alienated from everything, the world is irrational which is absent in the works of Aygy. The modernistic discourse does not interpret a man as a representative of a certain community, whereas the poet and the narrator communicate the philosophy of Chuvash ethnicity.

Aygy does not consider himself a modernist, probably, we ought to agree with that, since his narrator is given the feeling of responsibility, the orienting point is defined - creation; the idea of impossibility of progress is absent, he believes that the world is evolving and developing - this is the process of creation. The destructive conduct of the narrator is absent as well, however, the fact is that Aygy's narrator is a «representative of certain community»; his narrator is an earthy man, respecting the ancestors' traditions, i.e. the main features of modernism are excluded from his works, even though some characteristics, which we described above, can still be found in his verses.

To illustrate this we refer to the verse «Memoryfield». In this work the field, shining with «gold» ripe rye, maybe, oat, or wheat evokes in the poet's mind flowing associations; it reminds him of one field of old, its waft, where the poet dissolves in the «cage of spirit above the field». And the poet realizes that only when he is «sunk in darkness»", that is why the vision of the field moves his soul, bringing to memory voices which helped to remember other voices - «distant», that are keepers of looming symbols. It is clear that there is a wave of associations.

Aygy's lyrics are introverted, as absorption in the inner emotions of the narrator (who is the voice of the 
poet which is evident from the use of the pronoun «I») represents the guiding principle of Aygy's books. The outside world, given in a range of images, is subjectified, experienced. The inner emotions of the narrator are pointed at by: exclamations, aposiopeses, dash, which render the anxiousness of the poet. Epithets: «cold» prayer, «blissful» unconsciousness, «midday» light, «distant» meaning decorate the text, makes it more expressive and aesthetic. Reiteration «but remembering, but remembering», emphasizing the past, reflects its symbolism, creates a retrospective picture of the «field», «shining like gold».

Artistic devices highlight the expressiveness of the text, we can see this field, we experience almost the same feelings as the poet: sad and serene at the same time. The poet, reviving the past, again experiences that serenity of old - chastity, like a prayer, and this is done through the description of an ordinary field, in this, visually unremarkable field, all of a sudden one can hear a living soul - the creator hears these voices. And the voice of the poet's soul mixes with the voice of the soul of this field; the whole verse can be interpreted as an extended metaphor, the rhythm of which is supported by modulations of sounds lo, po, to, bo, po, mo, so, among them the key is lo - ol, reflecting the love of the poet towards his homeland.

Though the aesthetic concept of this verse as well as the whole body of Aygy's work is based on his love of native land, in his poems the word «light» is repeatedly used which forms the concept of search for light even in darkness. The poet knows that the world is binary and light and darkness are always together which is discussed in the article of N.G. Murzina, S.S. Safonova, A.O. Chaprukova «Native / foreign binary opposition as a way to conceptualize the artistic image of the world by V. Rasputin» [6].

We can see that a subjective moment in this verse grows to become infinite, the conscious of the narrator absorbs the entire world: voices, like prayers, («voices of the field» - «distant voices» - «those voices»), «cage of spirit» (i.e. moral values of his people), memory, as a binding thread between the past, present and future, leading towards the notion of self.

Through the infinitive form of the verb «continue» past, present and future are presented, time is infinite, it lasts forever, where there is the field, «gold» that continues to glisten, the topic of eternity is expressed through the predicate «keeps shining», which communicates the duration of the process of glowing, its infiniteness.

It can be concluded that certain impressionist trends evolve in the work of the poet, the most notable: growth of subjectivity, absorption of the entire world by the narrator's mind, aesthetisization of life, which both enriches the artistic vision (the real world is passed through the poet's soul and feelings), and narrows the space, representing the real human actions. The poet transfers into the space of personal sensations, perceptions, memories, introspections.

Remembering his «distant» field, the poet observes himself, his inner world, he begins to realise meaningfulness of the distant field, here emerges the «intuitive» feeling of how to become part of eternity: one has to be like the «field of old», to shine - that is the aesthetic concept of Aygy, so similar to the aesthetic concept of Charles Baudelaire, noted in the article «Power of imagination» that we in Nature «search for... meanings of words» [7], that it is a «dictionary» [7], V. Savin - the representative of Komi ethnicity, who was mentioned by T.L. Kuznetsova in the article «The literary traditions of Komi writer of prose E. V. Rochev»: «The humour culture of V. Savin is inspired by belief in life, the force of its eternal natural laws, unwavering power of the man; the mind of an artist which is grounded in contradictions, lit with kind and bright feeling. The author seems aspiring into future: that is the strength of his faith» [8].

Poetization and idealization of past is shown through the image of the field, the object of the physical world the field functions as a correlate from the space of memory - the field makes the poet realise the meaning and complexity of life (it consists of light and shade unity and struggle of two opposite origins of life, though the poet prefers a sober, similarly to Baudelaire («sunk in the darkness» - «in evil flowers»), outlook at the world. We can say that either the image of the field or other images carry the reflection of Aygy's aesthetic concept - to shine even in the dark, reflection of his moods, feelings.

The aesthetic concept of Aygy determines the external - stylistic (the form), and internal features (to shine, remaining patient, silent, to learn to hear silence). The external features are, firstly, Aygy's typical manner of presentation: description - reasoning through questions, judgements, lacunas, conclusions, secondly, as it has already been noted, the impressionist manner of presentation: a changing object is given via subjective perception and emotional experience of the poet which can be compared to Baudelaire; thirdly, introvertedness: immersion in inner feelings, nature-worship, abundance of lacunas, as signs of outer space, metaphors, symbols, allegories forms the leading principle of his lyrics. The poet has his roots in the mythological conscious of the Chuvash, his archetypes.

For the poet the reality, i.e. the objective reality, is the key pillar of his artistic reinterpretation, subjectification, which results in the secondary world - Aygy's world, realized in his works via the artistic method, based on the principle of aesthetisization of reality. The poet, as we noted, has his own stereotypic vision of the world universality, rooted in the special national world perception of the Chuvash, the world, as concentration of light, therefore such notions as «whiteness», «light», «serenity» occupy the key positions in his works, reflecting the world view of the Chuvash. This can be traced in other authors' works, including Michael Chabon, whose stereotypes are analysed and partially presented in the article by A.V. Strukova, O.O. Nesmelova, O.U. Ancyferova [9].

We selected as an example the work «Memory field». Within the Chuvash aesthetic framework the narrator in his search for the sense of life comes into the open field - the place of God; he addresses the memory, the «roots» which is so characteristic for the aesthetic of 
the Chuvash; he exercises patience. Devotion, prayerlike speech, appeal to heavens, worship of the field as if it is the entire earth (field-world), worship of God; preserving the communal spirit, uniformity which is inherent for this ethnicity, is visible in the poet's lyrics.

The internal features of his work include validation of cherishing every human being, the primacy of spirit, search for serenity, ability to see light in the dark, reveal the secrets of one's own soul and souls of others. According to Bubnova, the «psychological structure of meaning is a phenomenon of conscious, psychic phenomenon, formed in the process of individual perception and awareness of the world from the complexes of word features which are selected in the environment as a result of various activities» [10].

Therefore, the meaning of a word, throbbing in the artistic mind of the wordsmith, when considered in psychological terms, «it is its search», i.e. the process, or, "when taken in its broad sense, as a psychological equivalent of a «dictionary definition» - is both an object and a process, but by no means just an object» [11].

We think that the psychological method of the poet enables the creation of its equivalent in the lyrics of the XX century - it can be referred to as a representation in the form of a spiral; despite his inherent subjectivity, this form, as we believe, has great aesthetic value, as it presents the phenomenon of Aygy's flowing ideas, originating from the archetypes of ancestors' consciousness. The flow of ideas, started in the first verse in any of his books, keeps running, spiralling, reflecting the «roots» of ancestors, the light of the poet's soul. It, palpitating in the streams-words of the text, mixes in one current of the light, powerful in its source, nurtured by the gifts of land and heaven.

\section{Conclusions}

It can be concluded that the work of the given poet represents natural phase in literature development, therefore it contains a number of trends, following and enhancing them, being an essentially new phenomenon in the existing artistic system, reflecting the emerging features in the public conscious: search for sense is transferred «from the social and philosophical into the sphere of intuitive and aesthetic».

Creative work, according to the poet from Chuvashia, is «creative power», capable of making life whole» [12], this concept underlies the entire body of works of this wordsmith, forming the axis of his style, where the pivotal is «movement of thought» [2].

A concrete image is created by Aygy with the purpose to present an idea, this image is made for presentation of some thought, philosophical notion, time and space, life and death, fullness and emptiness. Any «matter» in Aygy's work is aimed at highlighting certain thought, concreteness in abstraction.

We claim that the visual world view of this poet is one of the essentials, his idea is shown through these images. The poet, seeing the tragedy of life, still extracts «hidden» in the world beauty, retains his position of a world citizen. Keen interest in life, inner world of a man, nature, phenomenon of creation, the position of an artist and a human in this world determine the leading motives of his verses. This is the key to understanding of his work.

$\mathrm{He}$, in his aesthetic, denies that image of life which humiliates and destroys a man as an individual, as he embodies the whole world, Universe.

His living principles of the master of the pen: reticence, concentration, maximum tension of mental and internal forces, life withstanding, resilience, craving for ideal.

Aygy's aesthetic system is whole, based on the world view of his people. He expresses in his work both «reach of land, and grieve of a man», his aesthetic is concrete, real, luminous.

\section{References}

1. M. M. Filippov, Features of western literature of the XYIII-XIX centuries (M.: Nauka, 1985)

2. S. N. Zenkin Works about French literature (Yekaterinburg: Ural University Publishing, 1999)

3. L. A. Mardieva Issues of psycholinguistics 1(27), 152-164 (2016)

4. A.M. Ivanova, Mediterranean Journal of Social Sciences 4(6), 353-358 (2015)

5. L. K. Bairamova, F. F. Gilemshin, V. N. Vassilieva, Journal of Language and Literature 7(1), 207-209 (2016)

6. N. Y. Murzina, S. S. Safonova, O. A. Chupryakova, Journal of Language and Literature 7(3), 80-84 (2016)

7. Baudelaire C. Salon of 1859. Power of imagination (Moscow, 1986)

8. T. Kuznetsova, Ural-Altaic Studies. Scientific Journal 2(17), 36-41 (2015)

9. A. V. Strukova, O. O. Nesmelova, O. U. Ancyferova, Ad Alta-journal of interdisciplinary Research 7(2), 306-308 (2017)

10. I. A. Bubnova, A. P. Klimenko, Issues of psycholinguistics 1(27), 60-71 (2016)

11. A. A. Leontiev, The psychological structure of meaning. The semantics of a word. Psycholinguistics (M.: Publishing «Nauka», 1971)

12. G. N. Aygy, However loud it would sound: to Vitaliy Amurskiy (G. Aygy about philosophy of G. Aygy) (Chavash en. 20-27 August, 1994) 